ションタンクに比較して，バイオフィルターの酸素溶解性能が優れていることが明らかになった。坑火石発泡 体を充填した装置では, 微生物保持濃度を $4,000 \mathrm{~g} \cdot \mathrm{m}^{-3}$ 以下に維持できれば, 最大 $3 \mathrm{~kg}-\mathrm{O}_{2} \bullet \mathrm{kWh}^{-1}$ 程度の動力効 率を期待できる。

\title{
化学酸化処理での反応生成物の遺伝毒性に関する研究
}

小野 芳朗* 宗宮 功* 河村 正純*

* 京都大学工学部衛生工学科

〈水質污濁研究 Vol. 14 No.9（1991） pp.633 641〉

水道水や下水処理水の塩素あるいはオゾンによる化学酸化処理によって生成するとされる化学物質の遺伝毒 性を，DNA 修復にともなう修復エラーを誘発する遺伝子量を測定する umu-テストを用いて評価した。

化学物質と試験菌体の反応時間 2 時間では，m-ジクロロベンゼン，1,2,4-トリクロロベンゼン，ブロモホル ムジクロロ酢酸，トリクロロ酶酸，クロラール，ホルムアルデヒド，イオノン，フルフラール，カルボン，グ リオキサール，アクロレインに陽性が認められた。これらの濃度効果の結果は，他のバクテリアアッセイの結 果と比較された。

またクロロホルム，ブロモホルム，トリクロロエチレン，アセチルアセトン，アクロレイン等には菌体との 反応時間を長くとることで遺伝毒性を増す傾向が認められた。これらょり，化学物質の種類により，細胞膜透 過やDNA の損傷，修復に差のあることが示唆された。 
文〉

\title{
好気性バイオフィルターにおける気液間酸素移動特性
}

$\begin{array}{lll}\text { 藤 江 幸 -* } & \text { 胡 洪 棠* } \\ \text { 池 田 康 郎* } & \text { 浦 野 紘 平* }\end{array}$

\section{Gas-Liquid Oxygen Transfer Characteristics in an Aerated Biofilter}

\author{
Koichi FUJIE*, Hong-Ying HU*, \\ Yasuo IKEDA* and Kohei URANO*
}

* Safety and Environmental Engineering Lab., Yokohama National Univ., 156 Tokiwadai, Hodogaya-ku, Yokohama 240 Japan

\begin{abstract}
Factors affecting the gas-liquid oxygen transfer characteristics in the biofilter with total floor coverage aeration are experimentally investigated. A formula for estimating $K_{L} a$ in the biofilter packed with ceramic balls of 6-23 mm in diameter was obtained as functions of the packing material size and the microbial concentration in it. It was ascertained that an increase in the microbial concentration hinders the gas-liquid oxygen transfer rate in the biofilter, while the rate is considerably higher than that in the activated sludge aeration tank. The packing materials in the biofilter control the bubble size and the spiral liquid circulation rate caused by air-lift action. The maximum power economy of oxygen transfer in the biofilter is as high as 3 $\mathrm{kg}-\mathrm{O}_{2} \cdot \mathrm{kWh}^{-1}$ provided that the microbial concentration is in the range of $2,000-4,000 \mathrm{~g} \cdot \mathrm{m}^{-3}$.
\end{abstract}

Key words: aerated biofilter, oxygen transfer, power economy, air diffuser performance factor

\section{1.はじめに}

好気性生物排水処理装置では，污濁物質の分解除去 を担っている微生物に酸素を供給するための電力が, 全消費電力の $40 \%$ 以上にも達しており，排水処理施設 での省エネルギーを実現するためには，まずエアレー ション動力の削減が必要である1),2)。好気性浸漬沪床 (以下，バイオフィルター)においても，エネルギー消 費を削減する目的で, 装置の最適な設計および運転操 作を行うためには，エアレーションにおける気相から 液相への酸素移動特性を十分に把握しておく必要があ る。

バイオフィルターにおける気相から液相への酸素供 給は, 1) 装置底部から沪材充填部に直接空気を吹き込
む方式，2)沪材充填部以外のところに散気を行い(気 泡存在部と呼ぶ), 溶存酸素濃度の上昇した排水を，工 アリフト作用によって沪材充填部に下降流で供給する 方式，および 3 ）表面䚓汼によって，気液間の酸素移 動と溶存酸素濃度の上昇した排水の汇材充填部への供 給を同時に行う方式に大別できる。2)の方式では, 気 液間および液相から生物膜表面への酸素移動抵抗に加 えて，酸素溶解を行っている気泡存在部と酸素を消費 している沪材充填部での酸素交換抵抗が存在する。気 泡存在部での酸素溶解性能が活性污泥エアレーション タンクに等しければ，上記の酸素交換抵抗の存在に よって,バイオフィルター装置全体での酸素溶解性能 は，活性污泥エアレーションタンクを上回ることはな (3)。3)の方式による酸素溶解性能は, 散気方式を上 
回るとされているが4), 空吵率の小さなバイオフィル ターでは液が混合されにくく，酸素溶解性能の実測結 果は報告されていない。

本研究では,上記した 1 ) の方式すなわち全面ばっ気 方式のバイオフィルターにおける，酸素溶解性能に対 する影響因子の解析，および活性污泥エアレーション タンクにおける酸素溶解性能との比較検討を行った。 すなわち, 酸素移動容量係数 $\mathrm{K}_{L} \mathrm{a}$ と通気量との関係に 対する，充填担体の形状および大きさ，装置内に保持 されている微生物濃度の影響を明らかにし， $K_{L} a$ を通 気量および各影響因子の関数として表示することを試 みた。さらに，酸素溶解性能を定量的に表示できる散 気性能指標 ${ }^{5}$ および，単位動力消費当りに溶解できる 酸素量として定義される酸素溶解の動力効率を指標と して，バイオフィルターにおける酸素溶解性能を評価 した。

\section{2. 実験}

\section{1 実験装置および充壃担体}

実験装置の本体には，内径 $12 \mathrm{~cm}$ ，高さ $120 \mathrm{~cm}$ の透明 塩化ビニール製カラムを用い，カラム内充填層高は85 $\mathrm{cm}$, 有効液深は $105 \mathrm{~cm}$, 担体充填体積は9.6l とした。 散気装置には, 直径 $1 \mathrm{~mm}$ の細孔を20個持った内径 13 $\mathrm{mm}$ の多孔管を用いた。実験に用いた充填担体の名称, 材質，大きさ，湿潤密度をまとめて Table 1 に示した。 アルファベットは材質を，つづく数值は担体の代表径 を表している。K は球形の坑火石発泡体 (Table 1 では Ceramic ball と表示した）であり，平均密度は 1,000 $\mathrm{kg} \cdot \mathrm{m}^{-3}$ 以下であるが, ばらつきがあるので一部は沈降 する。この担体をカラムに充填するときには，上部に 金網を設置して担体の流動化を抑えた。A は破砕状の アンスラサイト担体, PVA8はポリビニールアルコー ルゲル表面に粉末活性炭を付着した平均径が約 $8 \mathrm{~mm}$ の担体, PS3は直径 $3 \mathrm{~mm}$ のポリスチレン棒を $3 \mathrm{~mm}$ の長さに切断した担体である。

Table 1 Packing materials used for the experiments

\begin{tabular}{|lcccc|}
\hline \multicolumn{1}{|c}{ Name } & PC3 & PV8 & A2,A4,A5 & K6,K9,K13,K23 \\
\hline Materials & PS & PVA & A & K \\
Size, $\mathrm{d}_{\mathrm{p}}$ & $3^{\phi} \times 3$ & 8 & $2-5$ & $6-23$ \\
$\begin{array}{c}\left(\times 10^{-3} \mathrm{~m}\right) \\
\text { Packed Void } \\
(-)\end{array}$ & 0.44 & 0.60 & 0.46 & 0.48 \\
$\begin{array}{c}\text { Wet Density } \\
\left(\mathrm{kg} \mathrm{m}^{-3}\right)\end{array}$ & 1100 & 1040 & 1440 & 970 \\
\hline
\end{tabular}

PS : polystyrene, PVA : polyvinylalchol gel, A : anthracite, $\mathrm{K}$ : ceramic ball

\section{2 生物膜の培養方法}

バイオフィルターにおける生物膜の培養には，別 報6)と同じグルコース, ペプトンおよびコーンス ティープリカーを主成分とする人工排水を用い，BOD 濃度が $250 \mathrm{~g} \cdot \mathrm{m}^{-3}$ になるように水道水を用いて調製し た。人工排水は，散気装置下部より上向流で装置内に 供給し，処理水はオーバーフローによってカラム上部 から流出させた。バイオフィルター内に一様な生物膜 を得るために，処理水を毎時 $60 l$ の流量でカラム底部 へ循環した。生物膜培養時の BOD 容積負荷は, $1 \sim 4$ $\mathrm{kg}-\mathrm{BOD} \cdot \mathrm{m}^{-3} \cdot \mathrm{d}^{-1}$ であり，実験はすべて $20 \pm 2^{\circ} \mathrm{C} て ゙$ 行った。バイオフィルター内微生物保持濃度および生 物膜厚は，別報 ${ }^{6)}$ の方法に従って決定した。

\section{$2.3 K_{L} a$ の測定方法}

\subsection{1 エアレーション排ガスの分析による $K_{L} a$ の} 決定

エアレーションを行っている装置内液相において酸 素消費が進行していれば, 液中の溶存酸素濃度 $C$ は飽 和濃度以下に維持され, 装置内での酸素利用率 $\eta_{e}$ と $K_{L} a$ との関係は次式で与えられる ${ }^{7), 8)}$

$$
K_{L} a=\frac{u_{g}\left[(1-\varkappa) Z_{i} \eta_{e}-\left\{1-(1-\varkappa) Z_{i}\right\}\right] \cdot \ln \left(1-\eta_{e}\right)}{\left(C_{0}-C / Z_{i}\right) \cdot v_{m} \cdot h}
$$

ここで, $u_{g}$ はバイオフィルター内ガス空塔速度, $Z_{i}$ は 供給空気の酸素モル分率, $v_{m}$ は酸素単位質量当りの気 相体積である。純酸素と平衡にある溶存酸素濃度 $C_{0}$ は，散気水深を $h$ とすれば，散気装置からの鉛直距離 $l$ の関数として次式で与えられる。

$$
C_{0}=C_{0} * \cdot\{1+\xi(h-l)\}
$$

ただし， $C_{0}{ }^{*}$ は大気圧 $P^{*}$ における $C_{0}$ であり，式(1)に よる $K_{L} a$ の決定には， $l=h / 2$ として得られる $C_{0}$ を用 いてよい ${ }^{8)}$ 。乡は圧力換算係数であり次式で与えられ る。

$$
\xi=\left(\rho \cdot g / P^{*}\right) \cdot\left(1-\varepsilon_{g}\right) /\left(1-\varepsilon_{S}\right)
$$

ここで， $\rho$ は液密度， $\varepsilon_{g}$ はガスホールドアップ，(1一 $\left.\varepsilon_{S}\right)$ はカラム内の空隙率であり，本実験では $1-\varepsilon_{s}=$ $0.44 〜 0.60$ であった。

$\eta_{e}$ と排ガス中の酸素モル分率 $Z_{e}$ との関係は次式で 与えられる。

$$
\eta_{e}=\left(Z_{i}-Z_{e}\right) /\left[Z_{i} \cdot\left\{1-(1-\varkappa) Z_{e}\right\}\right]
$$
ただし， ※は酸素を 1 モル消費したときに生成する二 酸化炭素のモル数であり，排ガス中の二酸化炭素モル 分率 $Z_{e}$ を用いて次式で与えられる。

$$
\varkappa=Z_{c}\left(1-Z_{i}\right) /\left(Z_{i}-Z-Z_{c} Z_{i}\right)
$$

すなわち，エアレーション排ガス中の酸素および二 酸化炭素のモル分率と液中溶存酸素濃度を同時に測定 することによって，実用装置であっても，その運転に 
何等支障を及ぼすことなく，任意の条件下における $K_{L} a$ を容易に知ることができる。

\subsection{2 $K_{L} a$ および気泡径の測定条件}

バイオフィルター内に微生物が保持されていれば, 污濁物質の除去に伴う酸素消費によって, 液中溶存酸 素濃度は飽和值より低く維持されるので, 生物膜の培 養に用いたと同じ人工排水を供給して $K_{L} a$ を測定し た。

一方，微生物による酸素消費がない場合には，酸素 要求物質として $25 \mathrm{~mol} \cdot \mathrm{m}^{-3}$ の亜硫酸ナトリウム（和光 純薬製，試薬 1 級）水溶液を用いた。ただし，亜硫酸 ナトリウムの酸素による酸化反応を促進する触媒は一 切添加していないので, 物理吸収の条件が満たされて (る7)。生物反応は進行していないので，排ガス中の二 酸化炭素濃度を測定する必要はない。水道水を用いて 上記濃度の亜硫酸ナトリウム水溶液を調製し， 0.05 $\mathrm{m}^{3} \cdot \mathrm{h}^{-1}$ の流量で装置内に連続的に供給しながら $K_{L} a$ を測定した。バイオフィルター内の空隙率を 0.5 とすれ ば, 液線速度は $9 \mathrm{~m} \cdot \mathrm{h}^{-1}$ となり, 直径 $3 \sim 6 \mathrm{~mm}$ の気 泡群の液に対する相対速度 (約 $540 \sim 720 \mathrm{~m}^{\circ} \cdot \mathrm{h}^{-1}$ ) に比較 して十分小さいので9), 気泡上昇速度に対して, 亜硫酸 ナトリウム水溶液を供給することによる影響は考えな くてよい。

多孔質板や剪断力を利用して微細な気泡を生成する 散気装置では, 電解質濃度が $15 \mathrm{~mol} \cdot \mathrm{m}^{-3}$ 以上になると, 生成気泡径が小さくなることが報告されている7)。し かし, 本実験では粗大な気泡を生成する多孔管を散気 装置として用いたことから， $25 \mathrm{~mol} \cdot \mathrm{m}^{-3}$ の亜硫酸ナト リウム水溶液では, 生成気泡径に対する電解質として の影響は小さい。微細な気泡を生成する散気装置を用 いたときの $K_{L} a$ および気泡径に対する亜硫酸ナトリ
ウムおよび電解質の影響については，著者らの別報》 を参照されたい。

エアレーション排ガス中の酸素および二酸化炭素モ ル分率の測定には，それぞれ磁気風式酸素ガス分析装 置 (富士電機製，ZAR 型) および非分散型赤外線二酸 化炭素分析装置（MSA 社製，202型）をそれぞれ用い た。水分を除去するため，排ガスをシリカゲル充填力 ラムに通してから, 分析装置に供給した。液中の溶存 酸素濃度は, 電極法(飯島精密工業製, B-100型)によっ て測定した。

バイオフィルター内部を写真撮影することは不可能 なので, 気泡径の測定には亜硫酸ナトリウム水溶液に よる反応吸収法を用いた。原理等の詳細については原 報 ${ }^{10), 11)}$ を参照されたい。気泡径測定時の亜硫酸ナトリ ウム濃度を $250 \mathrm{~mol} \cdot \mathrm{m}^{-3}$ とし,酸素による亜硫酸ナトリ ウムの酸化反応を促進する触媒として, 硫酸コバルト を $0.5 \mathrm{~mol} \cdot \mathrm{m}^{-3}$ 添加した。

\section{3．結果および考察}

\section{1 微生物を保持しないバイオフィルターの $K_{L} a$}

\section{$3.1 .1 K_{L} a$ および気泡径に対する充填担体の影響}

亜硫酸ナトリウム水溶液への酸素の物理吸収を利用 して測定された $K_{L} a$ に対する充填担体性状の影響を Fig. 1 に示した。ただし, 横軸は充填担体代表径 $\left(d_{p}\right)$ の逆数であり，原点は担体を充填していない通常の気 泡塔を示している。実線（坑火石発泡体）および破線 (その他の担体)で結ばれている実測点は，同一ガス空 塔速度 $u_{\mathrm{g}}$ における $K_{L} a$ である。坑火石発泡体につい ては，その形状掠よび密度はほほ一定で，大きさだけ が異なっており， $u_{g}$ の実測範囲では，K13が最大の $K_{L} a$ をもたらした。PV8の充填層では, $u_{g}$ が大きくな

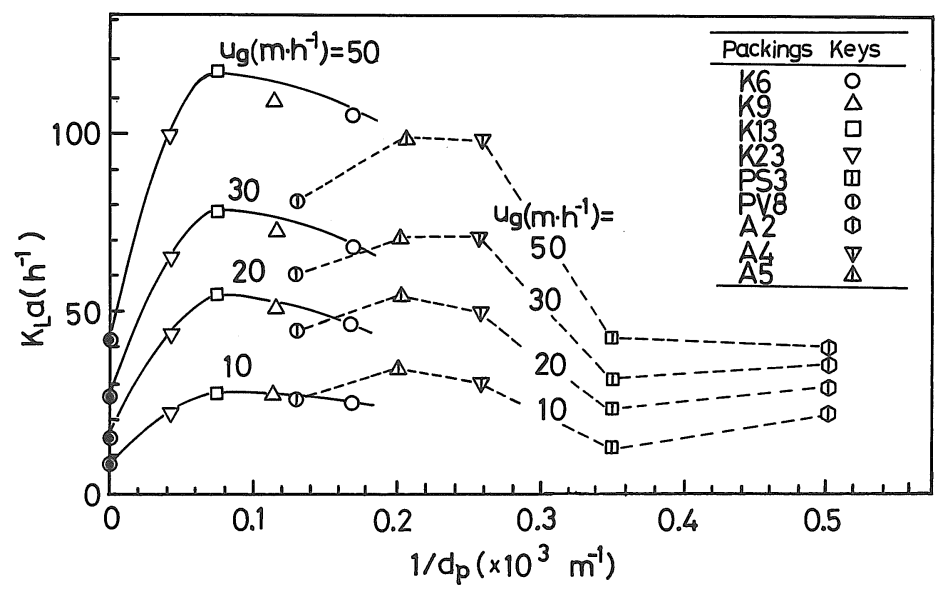

Fig. 1 Effect of packing material size on $K_{L} a$ at a constant superficial gas velocity $u_{g}$ in the biofilter. Concentric circles represent $K_{L} a$ in the bubble column without packing materials 


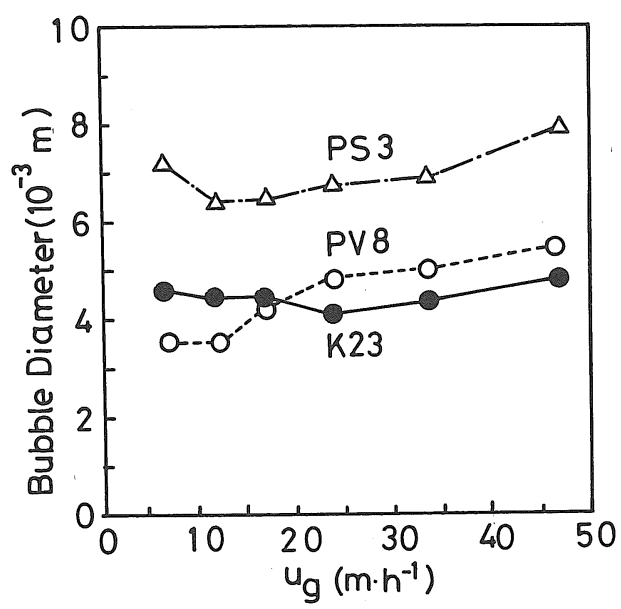

Fig. 2 Effects of $u_{g}$ and packing materials on bubble diameter in the biofilter

ると $K_{L} a$ の上昇は頭打ちとなる。PS3, A2等の小さい 担体の充填層では, $K_{L} a$ は他に比較して小さくなっ た。

反応吸収法によって実測された K23，PV8および PS3の充填層における気泡径に対する $u_{g}$ の影響を Fig. 2 に示した。ただし， $K_{L} a$ の測定時より亜硫酸ナ トリウム濃度が高いので，気泡径が小さくなっている 可能性がある。 $u_{\mathrm{g}}$ が大きくなると, K23では気泡径は あまり変化していないのに対して，PV8では気泡径が 大きくなっており,これが $K_{L} a$ の頭打ちをもたらした と考えられる。PS3の気泡径は他に比較して大きいの で， $K_{L} a$ は小さくなった。

すなわち，充填担体が小さくなると気泡の合一が促 進され，さらに担体の比重が 1 に近い場合には，合一 した気泡が充填層内を吹き抜けるようになるので, $K_{L} a$ は低下した。 $13 \mathrm{~mm}$ 程度の流動化しない担体の充 塡層での $K_{L} a$ が，他の担体に比較して大きくなった。

\section{1 .2 ガスホールドアップと $K_{L} a$}

バイオフィルター内を亜硫酸ナトリウム水溶液で満 たして十分に脱気した後, 液深を一定として通気を行 い，オーバーフローによって流出した液体積をまず測 定した。次いで，通気を停止して液を補給し，液面を 元の位置に戻すために必要な液の体積を測定した。前 者が通気時におけるバイオフィルターの全ガスホール ドアップ $\varepsilon_{g}$ に相当し, 後者がバイオフィルター内を流 動している気泡のガスホールドアップ（以下，流動気 泡ホールドアップ) $\varepsilon_{g a}$ に相当する。前者には，充填層 内に捕捉されて流動しない気泡のガスホールドアップ が含まれている。

K23およびPV8を充填したカラムにおいて実測さ

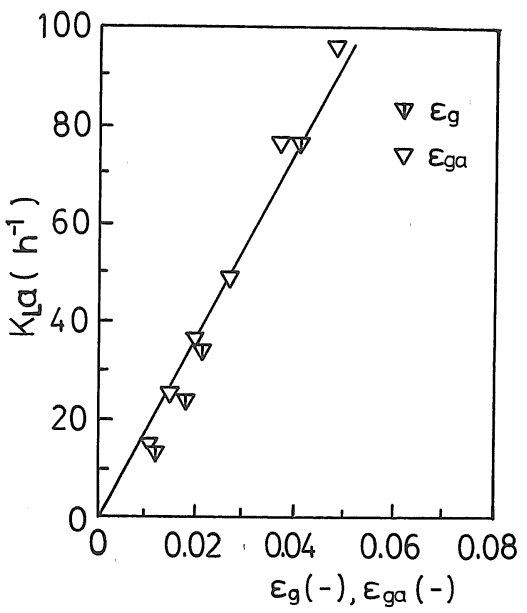

Fig. 3 Relationship between $K_{L} a$ and gas holdup $\varepsilon_{g a}$ in the biofilter packed with K23

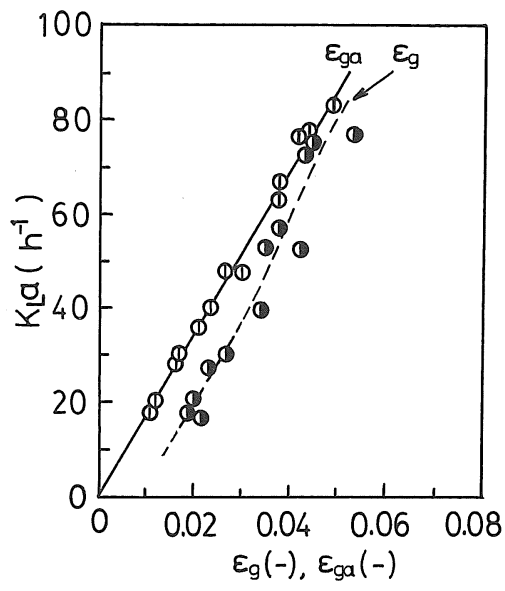

Fig. 4 Relationship between $K_{L} a$ and gas holdup $\varepsilon_{g a}$ in the biofilter packed with PV8

れた $\varepsilon_{g}$ および $\varepsilon_{g a}$ と $K_{L} a$ との関係を Fig. 3 および Fig.4に示した。K23 (Fig.3) では充填層内に気泡は 捕捉されないので $\varepsilon_{g}=\varepsilon_{g a}$ であり,$K_{L} a$ と $\varepsilon_{g}$ および $\varepsilon$ $g a$ との間には，いずれも原点を通る直線関係が得られ た。

一方，PV8 (Fig.4)では， $\varepsilon_{g}$ と $\varepsilon_{g a}$ との関係に大き な差があり, $K_{L} a$ と $\varepsilon_{g a}$ との間には, 原点を通る直線関 係が得られたが, $K_{L} a$ と $\varepsilon_{g}$ との関係は, 原点を通る直 線から大きく離れていた。ただし, $u_{g}$ が大きくなると， $\varepsilon_{g}$ と $\varepsilon_{g a}$ の差は小さくなり, 充填層内に捕捉される気 泡の体積が減少した。

どの担体でも， $K_{L} a$ と $\varepsilon_{g a}$ との間にほほ直線関係が 
得られたことは，流動気泡が酸素溶解に直接寄与して いることを示している。充填層内に捕捉された気泡中 の酸素モル分率は次第に低下するので, 酸素溶解に寄 与しなくなる。

\section{2 微生物を保持するバイオフィルターの $K_{L} a$}

\subsection{1 ガス空塔速度と $K_{L} a$ の関係}

充填担体表面に付着生育した微生物膜による人工排 水の処理を行いながら，エアレーション排ガスの分析 によって,バイオフィルターにおける $K_{L} a$ を決定し, $u_{g}$ との関係について Fig.5 (K23) および Fig.6 (K6)

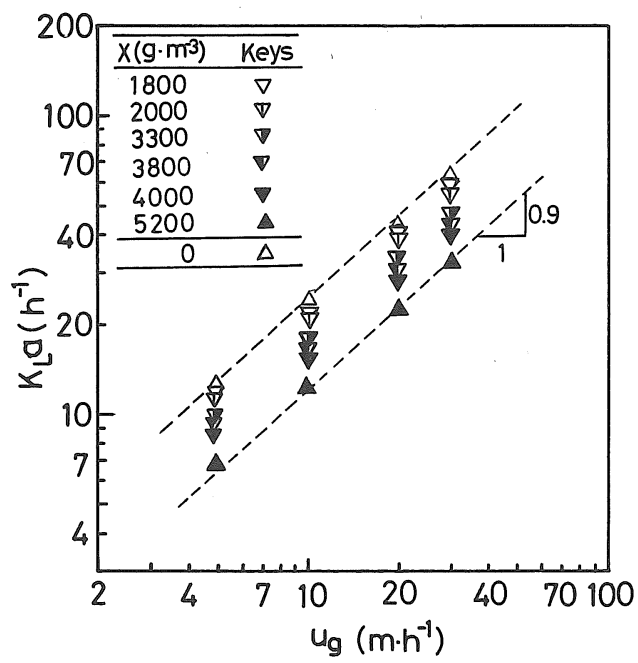

Fig. 5 Effect of microbial concentration $X$ on the relationship between $K_{L} a$ and $u_{g}$ in the biofilter packed with $\mathrm{K} 23$

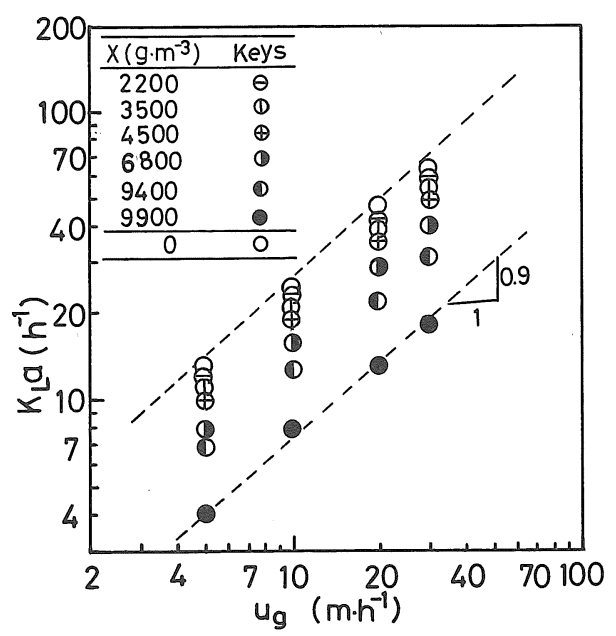

Fig. 6 Effect of microbial concentration $X$ on the relationship between $K_{L} a$ and $u_{g}$ in the biofilter packed with $\mathrm{K} 6$
に示した。バイオフィルター内での微生物保持濃度 $X$ とは，充填担体の表面に付着している微生物量を，バ イオフィルター単位体積当りの值として表示したもの である。

担体の大きさによらず $X$ の上昇は， $K_{L} a$ の低下を もたらしており，バイオフィルター内での $X$ の増大 は，気相から液相への酸素溶解性能を低下させること が分かった。さらに， $K_{L} a$ は $u_{g}$ の0.9乗に比例してお り，次式で近似できた。

$$
K_{L} a=\alpha \cdot u_{g}^{0.9}
$$

ただし， $\alpha$ は充填担体および $X$ にって決まる係数で あり，3.2.4で述べる。

\section{2 .2 ガスホールドアップと $K_{L} a$ の関係}

K23および K6を充填したバイオフィルターにおけ る $\varepsilon_{g a}$ と $K_{L} a$ との関係を, Fig.7 (K23) および Fig.8

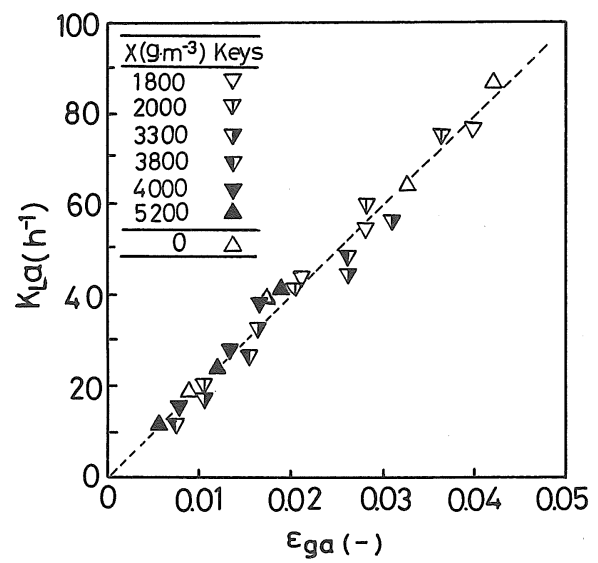

Fig. 7 Relationship between gas holdup $\varepsilon_{g a}$ and $K_{L} a$ in the biofilter packed with K23

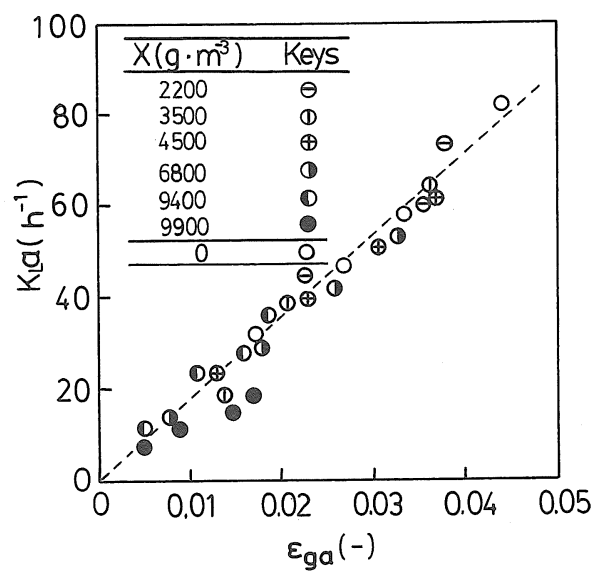

Fig. 8 Relationship between gas holdup $\varepsilon_{g a}$ and $K_{L} a$ in the biofilter packed with $\mathrm{K} 6$ 
（K6）に示した。 $X=0 \mathrm{~g} \cdot \mathrm{m}^{-3}$ における $K_{L} a$ は，生物膜 が付着していない状態で，亜硫酸ナトリウム水溶液を 用いて実測された結果である。多少のばらつきはある ものの，Xの大きさにかかわり無く，ほほ原点を通る 直線関係が得られている。なお，坑火石発泡体では $X$ が増大しても， $\varepsilon_{g}$ と $\varepsilon_{g a}$ には相違が見られず，バイオ フィルター内に気泡は捕捉されなかった。

$\varepsilon_{g a}$ と $K_{L} a$ との間に直線関係が得られたことと，式 (6)の関係より， $\varepsilon_{g a}$ は $u_{g}^{0.9}$ に比例している。さらにこの 関係は $X$ によって影響され，同じ $u_{g}$ でも $X$ が増大 すると $\varepsilon_{g a}$ が低下する。 $\varepsilon_{g a}$ が低下する理由について は，以下で述べる。

\subsection{3 バイオフィルター内での気泡上昇速度}

気泡混相流における気泡の液に対する相対速度（ス リップ速度） $u_{s}$ は，次式で与えられる。

$$
u_{s}=u_{g} / \varepsilon_{g a}-u_{L} /\left(1-\varepsilon_{g a}-\varepsilon_{s}\right)
$$

ただし， $u_{L}$ および $\left(1-\varepsilon_{g}-\varepsilon_{s}\right)$ は，それぞれバイオフィ ルター内での液空塔速度および液ホールドアップを示

している。

亜硫酸ナトリウム水溶液を供給している時の $u_{L}=9$ $\mathrm{m} \cdot \mathrm{h}^{-1}$ および人工排水を供給している時の $u_{L}=0.7$ $\mathrm{m} \cdot \mathrm{h}^{-1}$ をそぞれ式(7)に代入して得られる $u_{s}$ は, バイ オフィルター内での平均值である。液も $u_{L} /\left(1-\varepsilon_{g}\right.$ $\left.-\varepsilon_{s}\right)$ の速度でバイオフィルター内を上昇しているの で，実際の気泡上昇速度 $u_{B}$ は $u_{s}$ よりも大きくなる。 $u_{B}$ は式(7)に $u_{L}=0 \mathrm{~m} \cdot \mathrm{h}^{-1}$ を代入し， $u_{B}=u_{g} / \varepsilon_{g a}$ として 与えられる。ただし，本研究では $u_{L}$ が小さいので， $u_{B}$ $=u_{s}$ と見なしても大きな誤差にはならない。

バイオフィルター内での $X$ と $u_{s}$ との関係を Fig. 9 に示した。 $X$ の増大は顕著な $u_{s}$ の上昇をもたらし, $X$

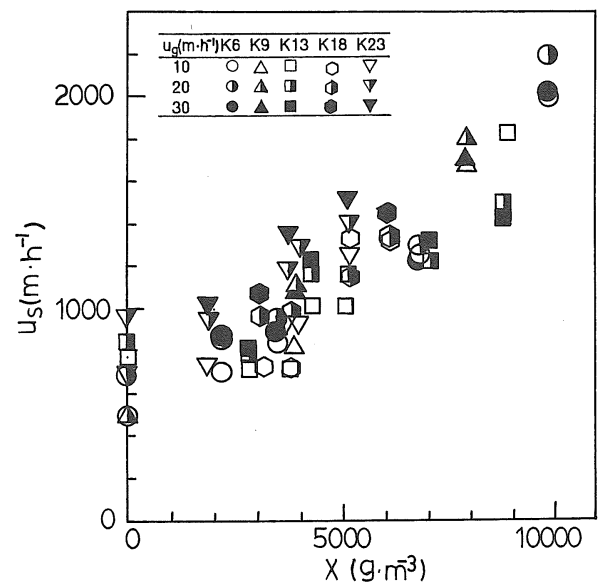

Fig. 9 Effect of microbial concentration, $X$, on the apparent bubble slip velocity, $u_{s}$, observed in the biofilter
が約 $8,000 \mathrm{~g} \cdot \mathrm{m}^{-3}$ を越えると， $u_{s}$ は $1,500 \mathrm{~m} \cdot \mathrm{h}^{-1}$ 以上に なった。充填担体表面に付着生育している生物膜の微 生物濃度は $30 \sim 40 \mathrm{~kg} \cdot \mathrm{m}^{-3}$ であるから ${ }^{6)}, X$ の増大はバ イオフィルター内空隙体積の減少をもたらす。 $X$ が $8,000 \mathrm{~g} \cdot \mathrm{m}^{-3}$ に達したときのバイオフィルター内空吵 率は, 0.25 程度まで低下した ${ }^{6)}$ 。充填層内空隙体積の減 少によって，気泡が上昇できる流路の断面積も小さく なるので気泡密度は上昇し，気泡間の合一が起こりや すくなるとともに，エアリフト作用による局所的な液 の上昇流が発生する。この液流に乗って，気泡がバイ オフィルター内を上昇するので，装置内での平均值と して決定される $u_{s}$ が大きくなり, 同時に $\varepsilon_{g a}$ の低下を もたらしたと考えられる。

充填担体が大きくなるか，あるいは $u_{g}$ が増大して も，致が大きくなる傾向が見られた。

\subsection{4 $K_{L} a$ に対する微生物保持濃度の影響}

$u_{g}$ と $K_{L} a$ との関係を式(6)によって近似できるとし て, 直径が $6 \sim 23 \mathrm{~mm}$ の坑火石発泡体を充填したバイ オフィルターにおける $\alpha$ 值と $X$ の関係を求め, 結果 を Fig. 10 に示した。担体の大きさにかかわりなく, $X$ の増大にともなって $K_{L} a$ は一様に低下している。Fig. 9 との対比から， $X$ の増大にともなう $u_{s}$ の上昇が $\alpha$ 值の低下に大きく寄与していると判断できる。 $X=0$ $\mathrm{g} \cdot \mathrm{m}^{-3}$ での $\alpha$ 值を $\alpha_{0}$ として, 各担体に対する值を Fig. 10 に示した。 $\alpha$ は $X$ 関係として次式で相関された。

$$
\alpha=\alpha_{0} \exp \left(-1.06 \times 10^{-4} X\right)
$$

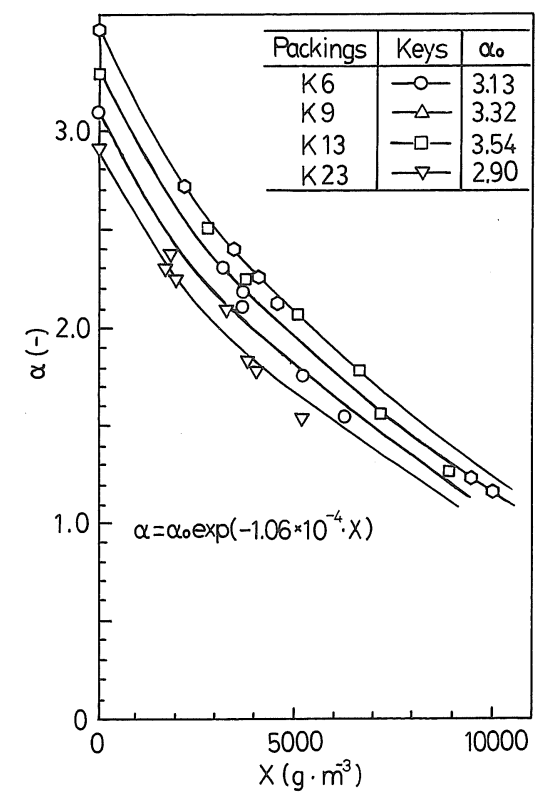

Fig. 10 Effect of microbial concentration $X$ on $\alpha$ value in Eqn.(6) for $K_{L} a$ evaluation 


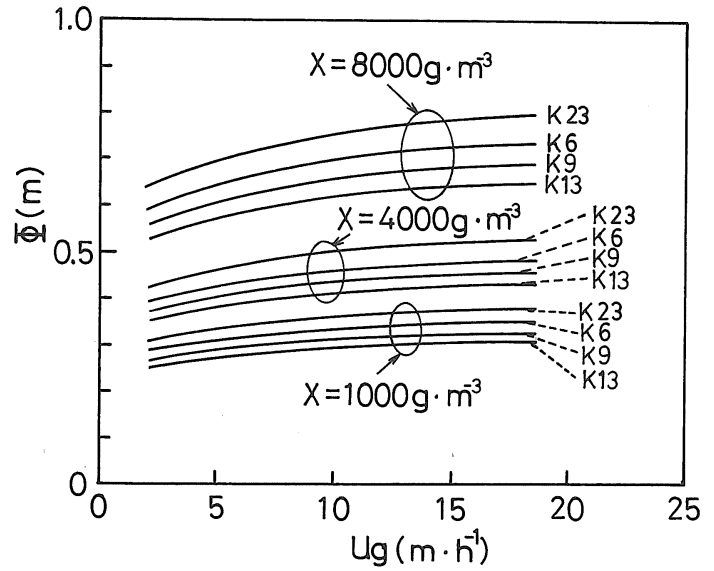

Fig. 11 Air diffuser performance factor $\Phi$ in the biofilter

Fig. 10 における実線は，式(8)による計算結果であ る。式(6)と式(8)によって, 坑火石発泡体を充填したバ イオフィルターにおける $K_{L} a$ を $X$ および $u_{g}$ の関数 として, 誤差 $\pm 20 \%$ の範囲で予測することが可能と なった。

\section{3 散気性能指標による酸素溶解性能の評価}

\subsection{1 バイオフィルターの散気性能指標}

活性污泥法プロセスのエアレーションタンクにおけ る酸素溶解性能については，久保田らによって定量的 な検討が行われており，エアレーションタンクの酸素 溶解性能を定量的に表示することができる指標とし て，次式で定義される散気性能指標 $\Phi$ の概念が提案さ れている5),8。

$$
\Phi=G_{V} \cdot h \cdot f / K_{L} a \cdot V
$$
ただし， $f$ は圧力補正係数であり，次式で与えられる。

$$
f=2 P^{*} /\left[P_{h}\left\{1+\left(P^{*} / P_{h}\right)^{1 / 2}\right\}\right]
$$

ここで, $G_{V}$ は標準状態での供給空気の体積流量, $V$ は エアレーションタンク容積であり， $G_{V} \cdot f$ はエアレー ションタンク内での水圧による体積変化を補正した吹 き込み空気の体積流量を示している。 $P^{*}$ および $P_{h}$ は，大気圧および散気水深 $h$ での圧力であり，通常の 散気液深 $(h=4 \sim 5 \mathrm{~m})$ では, $P^{*} / P_{h}\left\{1+\left(P^{*} / P_{h}\right)^{1 / 2}\right\}$ の 值は $0.73 \sim 0.77$ となる。

$\Phi$ の物理的意味は「液中に吹き込まれた空気中の酸 素が一定の割合で利用されるために必要な液深に比例 した值」であり，長さの次元 $(\mathrm{m})$ を持っている。小さ いథを与えるエアレーションタンクおよび散気装置 ほど，小さい液深で高い酸素溶解効果を与えるので, 酸素溶解性能が優れていると見なすことができる。市 販されている各種散気装置を設置したエアレーション

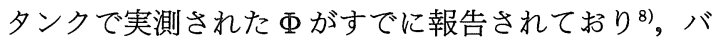

イオフィルターでの $K_{L} a$ から $\Phi$ を求めれば，活性污 泥エアレーションタンクの酸素溶解性能と定量的に比 較することができる。

式(6)および式(8)を式(9)に代入して次式が得られる。

$$
\Phi=f \cdot u_{g}^{0.1} / \alpha_{0} \exp \left(-1.06 \times 10^{-4} X\right)
$$

この式を用いて，坑火石発泡体を充填したバイオフィ ルターに打ける $\Phi$ を， $u_{g}$ 抒よび $X$ の関数として求め た結果を Fig。11に示した。

\subsection{2 活性污泥エアレーションタンクとの比較}

市販されている各種散気装置を設置したエアレー

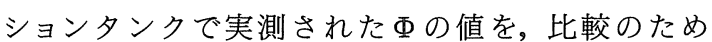
Table 2 に示した ${ }^{8)}$ 。超微細気泡系 (Very fine bubble) に分類される散気装置では，加圧水の噴出や機械的な 剪断力を利用して気泡の微細化を図っている。磁製散 気板などの多孔質材料を利用した散気装置が微細気泡 系 (Fine bubble) に分類される。粗大気泡系 (Coarse bubble）に分類される散気装置には，多孔管や簡単な ノズルなどがある。

バイオフィルターでは, $X$ が増大すると $\Phi$ が大きく なるものの，酸素溶解性能は，微細な気泡を生成する 磁製散気板を設置した活性污泥法エアレーションタン クを上回る。 $X$ が2, $000 \sim 4,000 \mathrm{~g} \cdot \mathrm{m}^{-3}$ のと，バイオ フィルター単位体積当りの BOD 除去速度が最大にな ることが分かっている6。

活性污泥エアレーションタンクでの気泡の液に対す る相対速度 $u_{s}$ は， $720 \mathrm{~m} \cdot \mathrm{h}^{-1}$ 程度であることが報告さ れている8)。ところが, 通常用いられている旋回流方式 のエアレーションタンクでは, 通気量が $u_{g}$ として 5 $\sim 10 \mathrm{~m} \cdot \mathrm{h}^{-1}$ 程度でも，液表面で $2,500 \sim 3,600 \mathrm{~m} \cdot \mathrm{h}^{-1}$ の 旋回流速が実測されており, 気泡存在部での液上昇速 度（前述の $u_{L}$ に相当する）は $1,000 \mathrm{~m} \cdot \mathrm{h}^{-1}$ 程度にな る ${ }^{12)}$ 。したがって，この方式のエアレーションタンクに おける気泡の上昇速度 $u_{B}$ は， $u_{s}$ と $u_{L}$ との和から

Table 2 Air diffuser performance factor $\Phi$ of various air diffusers for activated sludge aeration $\operatorname{tanks^{8)}}$

\begin{tabular}{|llc|}
\hline Classification & \multicolumn{1}{c|}{ Air diffuser } & $\Phi(\mathrm{m})$ \\
\hline Very fine bubble & MPC nozzle & $0.2-0.4$ \\
& Aquarator & $0.5-0.8$ \\
Fine bubble & Ceramic plate & $1.5-1.6$ \\
& Ceramic tube & $1.1-1.6$ \\
& Plastic porous tube & $1.6-1.9$ \\
& Jet aerator & $1.7-1.8$ \\
Coarse bubble & Line mixer aerator & $1.6-2.2$ \\
& Perforated tube & $2.2-3.5$ \\
& Sparger & $3.1-3.7$ \\
\hline
\end{tabular}


$1,700 \mathrm{~m} \cdot \mathrm{h}^{-1}$ 以上に達する。Fig.9 に示されているよう に，担体の大きさによる多少の違いはあるものの， $u_{g}$ が $30 \mathrm{~m} \cdot \mathrm{h}^{-1}$ に達しても $X$ が $8,000 \mathrm{~g} \cdot \mathrm{m}^{-3}$ 以下であれ ば,バイオフィルターにおける $u_{B}$ は $1,500 \mathrm{~m} \cdot \mathrm{h}^{-1}$ 以下 である。活性污泥エアレーションタンクにおけるエア リフト作用による液の旋回流は，活性污泥の沈降を抑 制できる代わりに，液中に吹き込まれた気泡の滞留時 間を短縮し，酸素溶解性能を低下している。これに対 してバイオフィルター内では, 充填担体の存在によっ てエアレーションタンクほど安定した液旋回流（液上 昇流）が発達しにくいので，気泡の上昇速度は活性污 泥エアレーションタンクに比較して小さくなる。また, エアレーションタンク内での気泡径は，通気量の増大 とともに大きくなるが8), バイオフィルター内では充 填担体の寄与によって，気泡が分散されるので，気泡 径に余り大きな変化はない。これらがバイオフィル ターにおける酸素溶解性能を, 活性污泥エアレーショ ンタンクに比較して優れたものにしている。

\section{4 酸素溶解の動力効率}

バイオフィルター単位体積当りの酸素溶解速度 $Q_{c}$ $\left(\mathrm{g} \cdot \mathrm{m}^{-3} \cdot \mathrm{h}^{-1}\right)$ は， $\Phi$ と $u_{g}\left(=f \cdot G_{v} \cdot h / V\right)$ および液中 溶存酸素濃度 $C$ の関数として次式で与えられる。

$$
\begin{aligned}
Q_{c} & =K_{L} a\left(C_{0} Z-C\right)_{a v} \\
& =\left(f \cdot G_{v} \cdot h / V \cdot \Phi\right)\left(C_{0} Z-C\right)_{a v}
\end{aligned}
$$

ここで,酸素移動の推進力 $\left(C_{0} Z-C\right)_{a v}$ は, 飽和溶存酸 素濃度と液中溶存酸素濃度の差の装置内平均值として 与えられる。

一方，断熱圧縮を仮定すれば；装置底部から液中に 空気を吹き込むためのブロワーの所要動力 $P_{w}(\mathrm{~kW})$ は，通気量 $G_{v}$ ，ブロワー入口での圧力 $P_{1}$ および出口 での圧力 $P_{2}$ の関数として, 次式から求めることができ る。

$$
P_{w}=0.0984 G_{v}\left\{\left(P_{2} / P_{1}\right)^{0.286}-1\right\} / \varepsilon_{B}
$$
ただし， $\varepsilon_{B}$ はブロワーと電動機を含む総合効率であ る。

したがって, 単位動力消費当りに溶解できる酸素量 として定義される酸素溶解の動力効率 $\psi\left(=Q_{c} / P_{w}\right.$, $\left.\mathrm{kg}-\mathrm{O}_{2} \cdot \mathrm{kWh}^{-1}\right)$ は, 以下のように求めることができる。

$$
\begin{aligned}
\psi & =\frac{\left\{\left(f \cdot G_{v} \cdot h / V \cdot \Phi\right) \cdot \varepsilon_{B} \cdot\left(C_{0}-C\right)_{a v}\right\} / 1,000}{0.0984 G_{v}\left\{\left(P_{2} / P_{1}\right)^{0.286}-1\right\}} \\
& =\frac{0.0102 \cdot f \cdot h \cdot \varepsilon_{B} \cdot\left(C_{0} Z-C\right)_{a v}}{\Phi\left\{\left(P_{2} / P_{1}\right)^{0.286}-1\right\}}
\end{aligned}
$$

ただし， $\Phi$ は式(11)で与えられている。 $\varepsilon_{B}=0.5$ および $h$ $=5 \mathrm{~m}$ として, $C=0 \mathrm{~g} \cdot \mathrm{m}^{-3}$ および $5 \mathrm{~g} \cdot \mathrm{m}^{-3}\left\{\left(C_{0} Z\right.\right.$

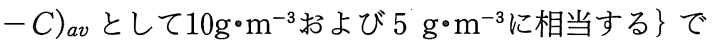
の $\Phi$ ととの関係を計算し, 結果を Fig. 12 に示し た。Fig. 11 との対比より, $X$ を $4,000 \mathrm{~g} \cdot \mathrm{m}^{-3}$ 程度に維持 できれば, $\Phi=0.5 \mathrm{~m}$ となり,$C=0 \mathrm{~g} \cdot \mathrm{m}^{-3}$ のとさひは $3 \mathrm{Kg}-\mathrm{O}_{2} \bullet \mathrm{kWh}^{-1}$ に達する。この值は, 磁製散気板など 微細気泡を生成散気装置の動力効率を $50 \%$ 程度上回っ ている。ただし，液中溶存酸素濃度を $0 \mathrm{~g} \cdot \mathrm{m}^{-3}$ として いることから, 最大の酸素溶解速度を見積ったことに なり, 実用運転では, 溶存酸素濃度の上昇によって動 力効率は低下し, 液中溶存酸素濃度が飽和濃度の $1 / 2 て ゙$ あれば，動力効率は図中の破線で与えられる。

$1 \mathrm{~kg}$ の BOD を除去するために必要な酸素量, すな わち酸素収率が与えられれば, バイオフィルターにお ける BOD 除去の動力効率，すなわち単位動力消費あ たりに除去できる BOD 量の予測が可能になった。

\section{4. 結 論}

バイオフィルターにおける $K_{L} a$ と通気量との関係 に対する，充填担体および微生物保持量の影響を実験 的に解析し, バイオフィルターにおける酸素溶解性能

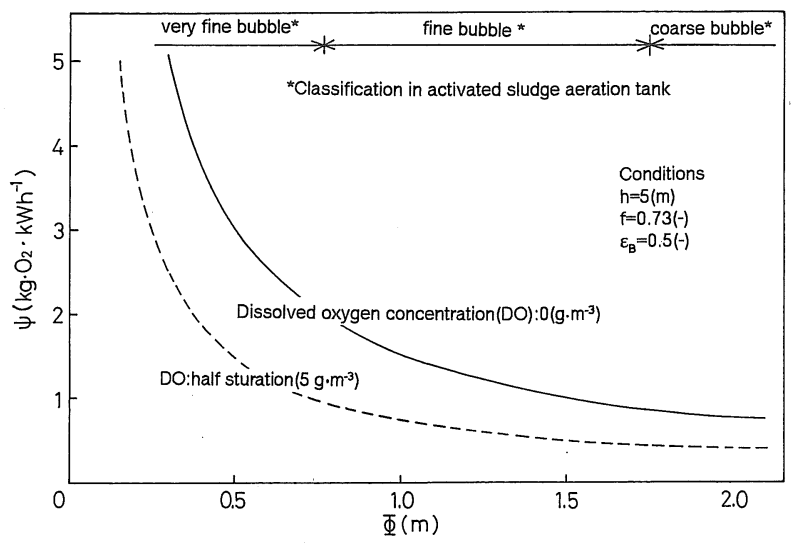

Fig. 12 Power economy of oxygen transfer, $\psi$, in the biofilter as a function of air diffuser performance factor, $\Phi$ 
の予測式を提出するとともに，酸素溶解性能について バイオフィルターと活性污泥法エアレーションタンク との比較を行い，以下の結論を得た。

1) 充填担体の性状はバイオフィルター内での気泡 径および気泡上昇速度に影響を及ぼし，球状の坑火石 発泡体を充填したバイオフィルターでは，直径が 13 $\mathrm{mm}$ 程度のとき, 同一通気量における $K_{L} a$ が最大とな る。

2 ) バイオフィルター内では安定した液旋回流が発 達しにくいことに加えて，気泡径の適度な分散状態が 得られるので, 活性污泥エアレーションタンクに比較 して，酸素溶解性能が優れている。

3 ) バイオフィルターにおける微生物保持量が大き くなると, $K_{L} a$ の顕著な低下をもたらすが，生物保持 濃度を $2,000 〜 4,000 \mathrm{~g} \cdot \mathrm{m}^{-3}$ に維持できれば，活性污泥 エアレーションタンクを約 $50 \%$ 上回る最大 $3 \mathrm{~kg}-\mathrm{O}_{2}$ 。 $\mathrm{kWh}^{-1}$ 程度の高い酸素溶解の動力効率が得られる。

（原稿受付 1991年 1 月 7 日）

(原稿受理 1991年6 月19日)

\begin{tabular}{|c|c|}
\hline & 使 用 記 号 \\
\hline$a$ & : 気液接触面積（m $\left.{ }^{-1}\right)$ \\
\hline C & ：液中溶存酸素濃度 $\left(\mathrm{g} ・ \mathrm{~m}^{-3}\right)$ \\
\hline$C_{0}$ & : 純酸素と平衡時の C $\left(\mathrm{g} \cdot \mathrm{m}^{-3}\right)$ \\
\hline$C_{0}{ }^{*}$ & : 大気圧下での $C_{0}\left(\mathrm{~g} \cdot \mathrm{m}^{-3}\right)$ \\
\hline$d_{p}$ & ：充填担体の代表径（m） \\
\hline$f$ & : 式(10)で与えられる圧力補正係数（一) \\
\hline$G_{V}$ & ：吹き込み空気の体積流量 $\left(\mathrm{m}^{3} \cdot \mathrm{h}^{-1}\right)$ \\
\hline$g$ & ：重力加速度 $\left(m \cdot \mathrm{s}^{-2}\right)$ \\
\hline$h$ & ：散気液深（m） \\
\hline$K_{L} \mathrm{C}$ & : 酸素移動容量係数 $\left(\mathrm{h}^{-1}\right)$ \\
\hline$l$ & : 散気装置からの鉛直距離（m） \\
\hline$P_{1}$ & : ブロワー入口圧力 $(\mathrm{Pa})$ \\
\hline$P_{2}$ & : ブロワー出口圧力 $(\mathrm{Pa})$ \\
\hline$P^{*}$ & : 大気圧 $(\mathrm{Pa})$ \\
\hline$P_{h}$ & ：散気液深での圧力（Pa） \\
\hline$P_{w}$ & : 散気動力（kW） \\
\hline$u_{B}$ & : 気泡上昇速度 $\left(m \cdot h^{-1}\right)$ \\
\hline$u_{g}$ & : 吹き込み空気の装置内空塔速度 $\left(\mathrm{m} \cdot \mathrm{h}^{-1}\right)$ \\
\hline$u_{L}$ & ：液空塔速度 $\left(m \cdot h^{-1}\right)$ \\
\hline$u_{s}$ & ：気泡の液に対する相対速度 $\left(m \bullet h^{-1}\right)$ \\
\hline$V$ & : 装置有効容積（m³） \\
\hline$X$ & : バイオフィルター内微生物保持濃度 $\left(\mathrm{g} \cdot \mathrm{m}^{-3}\right)$ \\
\hline$Z$ & : 気相中酸素モル分率 $(-)$ \\
\hline$Z_{c}$ & : 排ガス中の二酸化炭素モル分率 (-) \\
\hline$Z_{e}$ & : 排ガス中の酸素モル分率 (一) \\
\hline
\end{tabular}

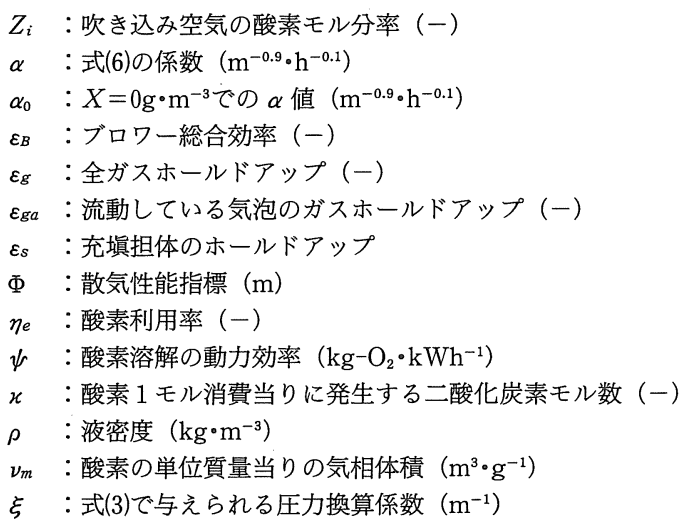

\section{引 用 文 献}

1 ) 藤江幸一 (1987) 生物排水処理と動力効率，化学と工業，40, 168-171.

2 ）藤江幸一，局俊明，久保田宏，渋谷伸一（1983）活性污泥処 理の動力効率の推算一実操業デー夕の解析結果に基づく数式 モデルの提案，下水道協会誌，20（227），25-32.

3 ) 藤江幸一, 久保田宏（1980）チューブ接触酸化排水処理装置 の動力効率，水質污濁研究，3，53-60.

4 ）藤江幸一（1980）生物排水処理装置の酸素移動と動力効率, 東京工業大学学位論文。

5 ) 久保田宏, 星野定司, 笠倉忠夫 (1979) エアレーションタン ク内の酸素移動, 下水道協会誌, 16 (184)，12-18.

6 ) 藤江幸一, 胡洪営, 池田康郎, 浦野紘平 (1991) 好気性バイ オフィルターにおける生物膜の増殖と目詰まり係数, 水質污濁 研究, 14, 564-573.

7 ) Fujie, K., Tsuchiya, K. and Fan, L.S., Remarks on Determination of volumetric oxygen transfer coefficient by off -gas analysis, J. Ferment. Biotechnol., 投稿中.

8 ) Sekizawa, T., Fujie, K., Kubota, H., Kasakura, T. and Mizuno, A. (1985) Air diffuser performance in activated sludge aeration tanks, J. Water Pollut. Control Fed., 57, 53 -59 .

9) Fujie, K., Takaine, M. and Kubota, H. (1980) Flow and oxygen transfer in cocurrent gas-liquid downflow, 13,188 -193 .

10) Ogawa, S., Shimizu, Y., Tone, S. and Otake, T. (1982) Kinetics of the oxidation of aqueous sodium sulfite solution with water, J. Chem. Eng. Japan, 15, 400-402.

11) Ogawa, S., Yamaguchi, H., Tone, S. and Otake, T (1983) Gas-liquid mass transfer in the jet reactor with liquid jet ejector, J. Chem. Eng. Japan, 16, 419-425.

12）星野定司，久保田宏，笠倉忠夫，小山俊明（1977）活性污泥 法エアレーションタンク内の液旋回流速, 下水道協会誌, 14 (160), 22-30. 


\section{論 文 要 旨}

バッチ培養における Chlorella vulgaris および Microcystis aeruginosa の細胞外代謝不揮発性有機酸の 培養液中への蓄積

大村 達夫* 海田 輝之* 相沢 治郎* 小松 佳幸* 石崎 正志* 大沼 正郎*

* 岩手大学工学部土木工学科

〈水質污濁研究 Vol.14 No.9（1991） pp.615～623〉

藻類の細胞外代謝溶存有機物は共存微生物の増殖や，これらの微生物による分解によってもたらされる $\mathrm{CO}_{2}$ の供給により藻類自身の増殖を助長する可能性など，水域生態系に影響を与える重要な因子の一つと考えられ ている。

本研究においては，緑藻の Chlorella vulgaris と藍藻の Microcystis aeruginosa を無菌的に回分培養し，増殖 過程あるいは死滅過程での不揮発性有機酸の培養液中への蓄積の状況を調べた。

その結果, C. vulgaris は主要な不揮発性有機酸としてグリコール酸とシュウ酸を蓄積し, M. aeruginosa はグ リコール酸を蓄積することが明らかとなった。しかし, M. aeruginosa は有機物を利用して対数増殖する時は不 揮発性有機酸をほとんど蓄積しないことが分かった。

また，グルクロマトグラフィーの結果では，代謝有機物は 3 つ画群に分画された。これらの画群に含有さ れる DOC の変化を見てみるとC. vulgaris の場合，増殖期にはほぼ同じ割合で各画群を蓄積しているが，減衰 期には高分子成分と低分子成分の蓄積が顕著になった。一方，M. aeruginosa は，減衰期において高分子成分が 著しく高くなり低分子成分の約 2 倍になった。また，不揮発性有機酸は，低分子成分の第III画群の主要な成分 であることも明らかになった。

\section{好気性バイオフィルターにおける気液間酸素移動特性}

藤江 幸一* 胡 洪営* 池田 康郎** 浦野 紘平*

* 横浜国立大学工学部物質工学科

** 大日本インキ(侏)

〈水質污濁研究 Vol.14 No.9（1991） pp.624～632〉

装置底部全面から沪材充填部に直接空気を吹き込む方式の好気性バイオフィルターにおいて，気液間酸素移 動特性に対する影響因子を，実測データの解析に基づいて明らかにし，代表径 6〜23mm の球状坑火石発泡体 を充填した場合の $K_{L} a$ を, 充填担体の大きさおよび微生物保持濃度の関数として予測するための相関式を提案 した。さらに, 散気性能指標 $\Phi$ おび酸素溶解の動力効率を指標として, 酸素溶解性能を活性污泥エアレーショ ンタンクと比較したところ，充填担体の存在は気泡の分散と，装置内での液旋回流の発達を抑制することによ る気液接触面積の増大をもたらすので，磁製散気板など微細な気泡を生成する散気譬置を設置したエアレー 